\title{
Removal of Reactive Blue 21 (RB21) Phthalocyanine Dye from Aqueous Solution by Adsorption Process: a Review
}

\author{
Sanaa El Aggadi*, Abderrahim El Hourch \\ Laboratory of Materials, Nanotechnologies and Environment, Faculty of Sciences, \\ Mohammed V University in Rabat, 4 Avenue Ibn Battouta, BP:1014, Rabat, Morocco
}

Received: 19 April 2020

Accepted: 8 September 2020

\begin{abstract}
Phthalocyanine dyes are one of the major categories of reactive dyes. They are water-soluble metal complexes, mainly containing copper, that are resistant to bacterial degradation under aerobic and anaerobic conditions. In this review article, the authors present the removal of RB21 phthalocyanine dye in aqueous solution by adsorption based on the literature. Therefore, an exhaustive list of various adsorbents has been compiled here. Additionally, the performance of several adsorbents under different physico-chemical process parameters and their comparative adsorption capacity towards the adsorption of RB21 dye was also presented. Affective adsorption factors for the dye such as solution $\mathrm{pH}$, initial dye concentration, adsorbent dosage and temperature are also included.
\end{abstract}

Keywords: Reactive Blue 21, phthalocyanine dyes, decolorization, adsorption, dye removal

\section{Introduction}

The textile industry has created a big environmental problem because it is one of the most chemically intensive industries on the planet. Over 3600 individual textile dyes are nowadays manufactured by the industry [1]. Every year, approximately 200,000 tons of these dyes are lost in effluents during dyeing and finishing operations [2]. More than 8000 chemicals are used by the industry in various textile production processes. Table 1 lists some of these chemicals. Most of these chemicals are toxic and directly or indirectly harm human health. Large quantities of water are needed to

*e-mail: sanaa_elaggadi@um5.ac.ma treat textiles [3]. Dye, even in low concentrations, is visible and impacts both aquatic life and the food chain. The average concentration of dyes in textile wastewater is about $300 \mathrm{mg} \cdot \mathrm{L}^{-1}$ [4]. Disposal of this highly colored effluent in natural watercourses hinders the penetration of light, perturbs biological processes in the aquatic environment and gives an unpleasant aesthetic appearance [5]. Azo, anthraquinone, triarylmethane and phthalocyanine dyes are the most important dye groups [6]. Phthalocyanines are a group of dyes produced by the reaction of dicyanobenzene in the presence of a metallic type of $\mathrm{Cu}, \mathrm{Ni}, \mathrm{Co}$, Pt. Copper phthalocyanines are the main derivative of this dye class, due to their beautiful blue to green shades, high dyeing resistance, excellent chemical stability, light fastness and resistant to bacterial degradation under aerobic as well as anaerobic conditions [7-9]. However, the process wastewater from 
Table 1. Major chemicals and dyes used in synthetic textile mills [81].

\begin{tabular}{|c|c|c|}
\hline Sr No. & Chemical & Quantity Kg/month \\
\hline 1 & Acetic Acid & 1611 \\
\hline 2 & Ammonium Sulphate & 858 \\
\hline 3 & P V Acetate & 954 \\
\hline 4 & Wetting Agent & 125 \\
\hline 5 & Caustic Soda & 6212 \\
\hline 6 & Softener & 856 \\
\hline 7 & Organic Solvent & 247 \\
\hline 8 & Organic Resin & 5115 \\
\hline 9 & Formic Acid & 1227 \\
\hline 10 & Soap & 154 \\
\hline 11 & Hydrosulphites & 6563 \\
\hline 12 & Hydrochloric Acid & 309 \\
\hline 13 & Hydrogen Peroxide & 1038 \\
\hline 14 & Leveling \& Dispersing Agent & 547 \\
\hline 15 & Solvent 1425 & 321 \\
\hline 16 & Oxalic Acid & 471 \\
\hline 17 & Polyesthylene Emulsion & 1174 \\
\hline 18 & Sulphuric Acid & 678 \\
\hline 19 & Disperse Dyes (Polyester) & 1500 \\
\hline 20 & Vat Dyes (Viscose) & 900 \\
\hline 21 & Sulphur Dyes & 300 \\
\hline 22 & Reactive Dyes & 45 \\
\hline
\end{tabular}

the copper phthalocyanine production plant contains a high COD (Chemical Oxygen Demand) content and a considerable amount of copper. The result of this type of contamination can cause the formation of a mixed effluent, containing heavy metal ions and organic matter indicating a toxicity measure [10]. Various methods have been developed for the elimination of copper phthalocyanine dyes from the wastewater in order to reduce their environmental impact [11-16]. Adsorption is one of the principle methods employed in wastewater for the removal of dyes, due to its universality, affordability and ease of use [17]. The objective of this review is the compilation of different adsorbents for the removal of the reactive blue 21 phthalocyanine dye in aqueous solution.

\section{Adsorption}

Many dye removal methods have been tested and proven, including adsorption (physical method), which has emerged as one of the preferred dye removal techniques because of its exceptional ability to remove almost all types of dyes [18-20]. The adsorption means the deposition of a substance at the interface between two phases (gas-solid or liquid-solid). The substance that accumulates at the interface is called an adsorbate and the solid on which adsorption occurs is an adsorbent [21]. There are two types of adsorption: chemical sorption and physical sorption. Chemical adsorption or chemisorption is illustrated by the formation of strong chemical bonds between the molecules or ions of the adsorbate on the surface of the adsorbent, which is usually due to the exchange of electrons and therefore chemical sorption is usually irreversible. Physical adsorption or physisorption is characterized by weak van der Waals intraparticle bonds between the adsorbate and the adsorbent and therefore reversible in most cases [22]. This process offers a good alternative for the treatment of polluted water, especially if the sorbent is economical and doesn't necessitate an additional pretreatment step prior to its application [21]. The handicap of this method was the high cost of adsorbents, but with the discovery of inexpensive adsorbents that were just as effective, this method has become an economical method of dye removal around the world [23-25]. Several adsorbents are successfully used for the removal of RB21 phthalocyanine dye.

\section{Activated Carbon}

Activated Carbon is a remarkable highly adsorbent material that has a wide range of applications in the remediation of groundwater contamination and industrial wastes such as colored effluents [26,27]. Activated carbons have a wide range of surfaces which generally vary between 500 and $1500 \mathrm{~m}^{2} \cdot \mathrm{g}^{-1}$, even up to $3000 \mathrm{~m}^{2} \cdot \mathrm{g}^{-1}$ [28]. they can be produced from any material having high percentages of carbon in its composition. Preferable characteristics of activated carbons are their affinity for various compounds, their large surface area and their ability to be regenerated [29]. Activated carbon is effective in removing all types of dyes and a variety of pollutants from wastewater [30]. The application of activated carbon for the treatment of RB21 dye has been reported by Shakoor et al. (2016). It is prepared according to the experimental protocol [31]. The batch adsorption process was affected by the agitation speed within the range of 130-300 rpm, sorbent dose ranging from 0.4 to $1.3 \mathrm{~g}$, the dye concentration from 2 to $16 \mathrm{ppm}$ and the $\mathrm{pH}$ value between 3 and 8 . The best removal of RB21 dye was obtained with a stirring speed of $210 \mathrm{rpm}$, a sorbent dose of $1.0 \mathrm{~g}$, a dye concentration of $6 \mathrm{ppm}$ and a $\mathrm{pH}$ of 3 . The maximum adsorption capacity calculated using Langmuir isotherm model was found to be $7.08 \mathrm{mg} \cdot \mathrm{g}^{-1}$ [31].

\section{Clinoptilolite}

Clinoptilolite represents the most abundant natural zeolite and is used extensively throughout the world. Its 
typical chemical formula is $(\mathrm{NaKCa})_{4}\left(\mathrm{Al}_{6} \mathrm{Si}_{30} \mathrm{O}_{72}\right) \cdot 24 \mathrm{H}_{2} \mathrm{O}$, and it is one of the unique candidates for adsorption of organic pollutants because it has special properties such as suitable structure, high stability, high cation exchange potential, cost-effectiveness and abundant distribution [32-34]. It has a characteristic tabular morphology showing an open reticular structure of easy access, formed by open channels of 8 to $10 \mathrm{limb}$ rings. It was demonstrated that clinoptilolite has a high selectivity for certain pollutants [35,36]. Sismanoglu et al. (2010) reported the application of clinoptilolite for the removal of RB21 dye. This adsorbent was used directly for adsorption experiments without any treatment. The adsorption of the reactive dye RB21 on the clinoptilolite was investigated in a batch model. The initial concentration of the dye is between 10 and $250 \mathrm{mg} . \mathrm{L}^{-1}$ prepared with doubly distilled water, $0.1 \mathrm{~g}$ of clinoptilolite and $10 \mathrm{~mL}$ of solution were stirred with a water bath to control the temperature at $25^{\circ} \mathrm{C}$ without any change in the initial $\mathrm{pH}$ (7.6). The equilibrium time of adsorption was found to be $90 \mathrm{~min}$ for the clinoptilolite. The adsorption isotherm of RB21 on the clinoptilolite was well described by the Langmuir adsorption equation. The clinoptilolite monolayer coverage capacity for the RB21 dye was determined to be $9.652 \mathrm{mg} \cdot \mathrm{g}^{-1}$ [37].

\section{Polyurethane Foam}

Polyurethane foams (PUF) are considered to be suitable adsorbents for the retention of chemical substances because they are cheap and can be used without any prior treatment. In addition, PUF have an excellent chemical and thermal resistance, a high adsorption efficiency, the possibility of reuse after desorption of the colorants and a popularization [38, 39]. Due to the presence of polar and non-polar groups in their structures, PUF are able to retain different classes of substances. They can be applied for the retention of free molecules with high polarizability such as aromatic compounds, metal dithizonates or iodine, and also large anions with high polarizability [40,41]. The use of PUF for the treatment of the RB21 dye by de Jesus da Silveira Neta et al. (2011) has been reported. This adsorbent was used after rinsing with distilled water and drying at room temperature for 24 hours. The batch study using the Langmuir model was conducted to estimate the maximum adsorption capacity of the dye RB21 by the PUF. $80 \mathrm{mg}$ of adsorbent in 15 $\mathrm{mL}$ aqueous dye solution were used at concentrations of $10-60 \mathrm{mg} \cdot \mathrm{L}^{-1}$ with keeping the $\mathrm{pH}$ value at 2 . The equilibration time of adsorption was $180 \mathrm{~min}$ for PUF. The maximum adsorption capacity of PUF for the RB21 dye was 8.31 mg.g ${ }^{-1}$ [42].

\section{Chitosan/Polyamidoamine}

Chitosan is one of the most promising and applicable materials in adsorption applications. Besides its physical properties (macromolecular structure, lowcost, non-toxicity, biocompatibility, biodegradability, etc.) [43], and its applications in many fields (cosmetics, medicine, biotechnology, membranes, food industry, etc. [44-47], chitosan was given particular attention as a functional material because of its adsorption potential. The presence of amino and hydroxyl groups in its molecules contributes to many possible adsorption interactions between chitosan and pollutants (dyes, metals, ions, phenols, pharmaceuticals compounds, pesticides, herbicides, etc.) [48, 49]. As is well known, the major advantage of chitosan is the existence of modifiable positions in its chemical structure [50]. Several functional groups have been introduced to modify chitosan to increase their adsorption capacity and improve their adsorption selectivity [51-53]. Chitosan/ polyamidoamine (PAMAM) has been reported to be an effective modification of chitosan for the removal of heavy metals and dyes in aqueous solution $[54,55]$. Recently, many studies have reported the removal of dyes and metal ions using magnetic chitosan composite (MCS) adsorbents. The application of MCS/PAMAM for the removal of RB21 dye from the aqueous solution has been reported by Wang et al. (2015). MCS/PAMAM is well prepared following the experimental protocol [54]. The batch adsorption experiments were influenced by the adsorbent dose ranging from 5 to $50 \mathrm{mg}$, the dye concentration from 40 to $100 \mathrm{mg} \cdot \mathrm{L}^{-1}$, and the $\mathrm{pH}$ value between 2 and 11 . The equilibrium time of adsorption was found to be 720 min. Adsorption capacity decreased from 390.69 to $159.04 \mathrm{mg} \cdot \mathrm{g}^{-1}$ when the dose of MCS/PAMAM was increased from 5 to $50 \mathrm{mg}$. The adsorption capacity reached a maximum of $201.16 \mathrm{mg} \cdot \mathrm{g}^{-1}$ at $\mathrm{pH} 6$. The amount of dye adsorbed increased from 97.27 to 221. $06 \mathrm{mg} \cdot \mathrm{g}^{-1}$ with an increase in the initial concentration from 40 to $100 \mathrm{mg} \cdot \mathrm{L}^{-1}$, The maximum adsorption capacity calculated using Langmuir isotherm model was found to be $200 \mathrm{mg} \cdot \mathrm{g}^{-1}$ [54].

\section{Chitosan-Zirconium Phosphate}

Zirconium bis-(monohydrogen orthophosphate) monohydrate $\left(\mathrm{Zr}\left(\mathrm{HPO}_{4}\right)_{2} \mathrm{H}_{2} \mathrm{O}\right)$, also known as layered $\alpha$-zirconium phosphate $(\mathrm{ZrP})$, is attracting increasing attention because of its ability to act as an ion exchanger, catalyst and intercalation support due to its lamellar structure and abundant hydroxyl groups [56]. Nevertheless, the disadvantage of these materials for practical applications is their microcrystalline nature which limits adsorbent recovery in discontinuous systems and affects the hydrodynamic properties of fixed bed systems [57]. This can be circumvented by immobilizing, grafting or encapsulating these materials in polymers $[58,59]$. Chitosan has an inherent affinity with $\mathrm{ZrP}$, it was felt that chitosan-layered $\mathrm{ZrP}$ (CZrP) could have dye adsorption potential. Bhatt et al. (2019) reported the application of $C Z r P$ for the removal of RB21 dye. CZrP is well prepared following 
the experimental protocol [57]. Batch adsorption experiments were conducted at $30^{\circ} \mathrm{C}$ with stirring at $200 \mathrm{rpm}$, the adsorbent dose $(\mathrm{CZrP})$ of $0.05 \mathrm{~g}$ was used with $25 \mathrm{~mL}$ of dye $(100 \mathrm{ppm})$ at contact time $=210 \mathrm{~min}$, with $\mathrm{pH}$ ranging from 1 to 10 . The maximum adsorption capacity was observed in the $\mathrm{pH}$ range $3-5$. The maximum adsorption capacity calculated using Langmuir isotherm model was found to be 457 mg. $\mathrm{g}^{-1}$ occurred at acidic ( $\left.\mathrm{pH} 3\right)$.

\section{The Modified Microcrystalline Cellulose}

Microcrystalline cellulose (MCC) is a purified hydrolyzed crystalline form of cellulose that appears as a white, odorless, tasteless, and crystalline powder with porous structure [60]. MCC is a practical material with excellent properties for the pharmaceutical, cosmetic, food, polymer composite and other industries [61]. It offers advantages such as low cost, low density and low abrasion of process equipment [62]. Chemical modification of the surface of MCC increases its adsorption capacity by enhancing its chemical and physical properties. The chemical modification of MCC by aminopropyltriethoxysilane (APTES) and hydroxypropyldodecyldimethylammonium and its uses in the removal of RB21 dyes are reported by Ravindra et al. (2019) and $\mathrm{Hu}$ et al. (2016) respectively. The MCC modified by APTES was well prepared according to the experimental protocol [63]. The batch adsorption experiments were affected by the $\mathrm{pH}$ value between 2 and 12 , the initial dye concentration of 40 to $120 \mathrm{mg} . \mathrm{L}^{-1}$, the adsorbent dose (MMCC) ranging from 0.1 to $0.3 \mathrm{~g}$, the temperature varying between 30 and $50^{\circ} \mathrm{C}$, and the contact time from 0 to $60 \mathrm{~min}$. The sorption of the dye decreases with increasing $\mathrm{pH}$ value, $\mathrm{pH}$ values of 2 were considered optimal for the adsorption of the dye RB21. Adsorption capacity increased from 8 to $20 \mathrm{mg} . \mathrm{g}^{-1}$ with an increase in initial dye concentration from 40 to 120 mg. $\mathrm{L}^{-1}$. The equilibrium time of adsorption was found to be $50 \mathrm{~min}$. The efficiency of dye removal increased from 70 to $94 \%$ with the increase of the adsorbent dosage. Further experiments with an adsorbent of more than $0.25 \mathrm{~g}$ showed that there was no change in the results. $0.25 \mathrm{~g}$ can be considered the optimal amount of adsorbent for discoloration. The adsorption

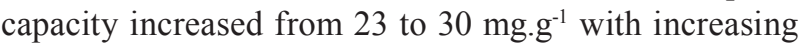
temperature. The Langmuir isothermal adsorption model demonstrates a good adjustment with the adsorption capacity of $30 \mathrm{mg} \cdot \mathrm{g}^{-1}$ at $50^{\circ} \mathrm{C}$ [63]. The MCC modified by hydroxypropyldodecyldimethylammonium is well prepared following the experimental protocol [12]. The batch adsorption experiments were affected by the $\mathrm{pH}$ value between 2 and 10, the initial dye concentration of 70 to $120 \mathrm{mg} . \mathrm{L}^{-1}$, and the contact time from 0 to $350 \mathrm{~min}$. Adsorption capacity reached $200 \mathrm{mg} \cdot \mathrm{g}^{-1}$ at initial $\mathrm{pH} 2$, at a loading of $400 \mathrm{mg}$. $\mathrm{L}^{-1}$ and at an initial concentration of $80 \mathrm{mg} . \mathrm{L}^{-1}$ for $180 \mathrm{~min}$. the Langmuir model best describes the adsorption process of the RB21 dye on MMCC, suggesting a monolayer adsorption process with no interaction between the adsorbed dye molecules, the maximum dye adsorption capacity of the Langmuir isothermal model at $40^{\circ} \mathrm{C}$ was $408.90 \mathrm{mg} \cdot \mathrm{g}^{-1}$ [12].

\section{Sepiolite}

Sepiolite is an abundant and cheap natural clay mineral. It is a hydrated magnesium silicate with a theoretical molecular formula of $\mathrm{Si}_{12} \mathrm{O}_{30} \mathrm{Mg}_{8}(\mathrm{OH})_{4}\left(\mathrm{H}_{2} \mathrm{O}\right)_{4} \cdot 8 \mathrm{H}_{2} \mathrm{O}[64,65]$. Its structure is a needle-shaped crystalline structure that grows in the direction of the fiber, composed of two tetrahedral silica sheets and a central octahedral magnesium sheet [66]. Because of the discontinuous octahedral sheets, several porous channels develop in the sepiolite structure, allowing access to contaminants in the structure [67]; it has been successfully used for the adsorption of various contaminants such as heavy metals, dyes, oils, carbon dioxide, hydrogen and phosphorus [64, 67-71]. Sepiolite is a great adsorbent for organic species because it has a variety of attractive properties such as high specific surface area, high porosity, and high chemical and mechanical stability [72]. Demirbas and Nas (2009) reported the use of the sepiolite for the treatment of RB21 dye. This adsorbent was used directly for adsorption experiments without any treatment. The batch adsorption tests were controlled by experimental parameters such as initial dye concentration (100-750 mg. $\left.\mathrm{L}^{-1}\right)$, $\mathrm{pH}$ (2-8), adsorbent dose (1-4 g.. $\left.{ }^{-1}\right)$ and temperature $\left(25-50{ }^{\circ} \mathrm{C}\right)$ during a contact time for a contact time of $16 \mathrm{~h}$. As the initial concentration increased from 100 to $750 \mathrm{mg} \cdot \mathrm{L}^{-1}$, the amount of RB21 adsorbed increased from 20.2 to $54.3 \mathrm{mg} \cdot \mathrm{g}^{-1}$. The amount of RB21 adsorbed increased

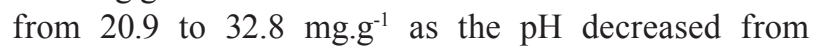
8 to 2 and the optimum $\mathrm{pH}$ value was found to be 2 . The quantity of adsorbed dye increased from 13.5 to $32.8 \mathrm{mg} \cdot \mathrm{g}^{-1}$ while reducing the adsorbent dosage from 4 to 1 g.L $\mathrm{L}^{-1}$. The maximum adsorption capacity of the dye increased from 48.1 to $60.8 \mathrm{mg} \cdot \mathrm{g}^{-1}$ as the temperature increased from 25 to $50^{\circ} \mathrm{C}$. The Langmuir isotherm provided the best correlation, the maximum dye adsorption capacity from the Langmuir isotherm model at $50^{\circ} \mathrm{C}$ was $66.67 \mathrm{mg} \cdot \mathrm{g}^{-1}[73]$.

\section{Fly Ash}

Fly ash (FA) is a by-product of the combustion of coal in the power production process. Fly ash has been used effectively for construction materials, soil amendment and fill materials, but it is unlikely that these applications will result in the reuse of all fly ash produced. Therefore, great efforts are being taken to explore other applications prior to disposal [74]. The reuse of FA as an adsorbent for the removal of different types of pollutants in wastewater has attracted a lot of attention. It has been used to remove heavy metals, dyestuffs from water, it is considered 
an effective adsorbent due to its hollow sphere and activated surface [11]. The application of FA for the elimination of RB21 dye from the aqueous solution has been reported by Demirbas and Nas (2009). This adsorbent was used directly for adsorption experiments without any treatment. The batch adsorption tests were affected by the initial dye concentration (100-750 mg. $\left.\mathrm{L}^{-1}\right)$, $\mathrm{pH}$ (2-8), adsorbent dose $\left(1-4\right.$ g. $\left.\mathrm{L}^{-1}\right)$ and temperature $\left(25-50^{\circ} \mathrm{C}\right)$ for a contact time of 16 hours. As the initial concentration increased from 100 to $750 \mathrm{mg} . \mathrm{L}^{-1}$, the amount of RB21 adsorbed increased from 36.3 to $80.4 \mathrm{mg} \cdot \mathrm{g}^{-1}$. The amount of $\mathrm{RB} 21$ adsorbed decreased as the initial $\mathrm{pH}$ increased and the optimum $\mathrm{pH}$ value of the dye was found to be 2 . The amount of RB21 adsorbed increased from 19.8 to $56.9 \mathrm{mg} \cdot \mathrm{g}^{-1}$ when the $\mathrm{pH}$ changed from 8 to 2 . The amount of adsorbed dye increased from 23.7 to $56.9 \mathrm{mg} \cdot \mathrm{g}^{-1}$ while reducing the adsorbent dosage from 4 to 1 g. $\mathrm{L}^{-1}$. The maximum adsorption capacity of the dye increased from 73.9 to $96.0 \mathrm{mg} / \mathrm{g}$ as the temperature increased from 25 to $50^{\circ} \mathrm{C}$. The Langmuir isotherm gave the best correlation, the maximum dye adsorption capacity of the Langmuir isothermal model at $50^{\circ} \mathrm{C}$ was $106.71 \mathrm{mg} \cdot \mathrm{g}^{-1}$ [73].

The Modified Carboxymethyl Cellulose $/ \mathrm{Fe}_{3} \mathrm{O}_{4}$

Cellulose is among the world's most abundant natural polymers, providing excellent biodegradability and biocompatibility. Nevertheless, the compact and inactive molecular structure of cellulose demands that it be modified to enhance its hydrophilicity as an adsorbent for the removal of dyestuffs. The sodium carboxymethyl cellulose (CMC) is a derivative representative of cellulose with carboxymethyl groups $\left(-\mathrm{CH}_{2} \mathrm{COONa}\right)$ attached to some of the hydroxyl groups in the cellulose backbone. The polar carboxyl groups make cellulose soluble, chemically reactive and highly chelated; therefore, the application of $\mathrm{CMC}$ in adsorption domains seems interesting and promising. Wang et al. (2016) reported the use of the magnetic $\mathrm{CMC} / \mathrm{Fe}_{3} \mathrm{O}_{4}$ modified with hydrazine for the treatment of $\mathrm{RB} 21$ dye. $\mathrm{CMC} / \mathrm{Fe}_{3} \mathrm{O}_{4}$ modified with hydrazine $\left(\mathrm{MCMC} / \mathrm{Fe}_{3} \mathrm{O}_{4}\right)$ is prepared in according to the experimental protocol [75]. The batch adsorption tests were impacted by initial $\mathrm{pH}(1.08-10)$, contact time $(0-700 \mathrm{~min})$, initial temperature $\left(30-60^{\circ} \mathrm{C}\right)$, adsorbent dose (20-80 mg. $\left.\mathrm{L}^{-1}\right)$ and initial dye concentration (40-100 mg. $\left.\mathrm{L}^{-1}\right)$. The elimination efficiency was found to decrease from $94.47 \%$ to $40.04 \%$ as the $\mathrm{pH}$ increased from 1.08 to 10.00 . The adsorption capacity completely reached equilibrium after $240 \mathrm{~min}$. Adsorption capacity was found to increase from 60.32 to $72.59 \mathrm{mg} \cdot \mathrm{g}^{-1}$ with increasing temperature from 30 to $60^{\circ} \mathrm{C}$. The adsorption capacity decreased from 101.84 to $31.10 \mathrm{mg} \cdot \mathrm{g}^{-1}$ as the adsorbent dose increased from 20 to $80 \mathrm{mg}$. The removal efficiency increased from $76.37 \%$ to $99.69 \%$ as the initial concentration increased from 40 to $100 \mathrm{mg} . \mathrm{L}^{-1}$. The Langmuir isotherm gave
Table 2. Maximum adsorption capacity of RB21 dye bye some adsorbents.

\begin{tabular}{|c|c|c|}
\hline Adsorbent & $\begin{array}{c}\text { Adsorption } \\
\text { capacity } \\
(\mathrm{mg} / \mathrm{g})\end{array}$ & Reference \\
\hline Activated carbon & 7.08 & {$[31]$} \\
\hline Clinoptilolite & 9.652 & {$[37]$} \\
\hline Polyurethane foam & 8.31 & {$[42]$} \\
\hline Chitosan/polyamidoamine & 666.67 & {$[54]$} \\
\hline CZrP & 457 & {$[57]$} \\
\hline MCC/APTES & 30 & {$[63]$} \\
\hline $\begin{array}{c}\text { MCC/hydroxypropyldodecyld- } \\
\text { imethylammonium }\end{array}$ & 409.9 & {$[12]$} \\
\hline Sepiolite & 66.67 & {$[73]$} \\
\hline Fly ash & 106.71 & {$[73]$} \\
\hline $\begin{array}{c}\text { The modified carboxymethyl } \\
\text { cellulose/ Fe } \mathrm{O}_{4}\end{array}$ & 126.58 & {$[75]$} \\
\hline $\begin{array}{c}\text { Sawdust biochar/Fe } \\
\mathrm{O}_{4}\end{array}$ & 27.77778 & {$[14]$} \\
\hline
\end{tabular}

the best correlation, the maximum dye adsorption capacity of the Langmuir isothermal model at $60^{\circ} \mathrm{C}$ was 126.58 mg.g $\mathrm{g}^{-1}[75]$.

\section{Sawdust Biochar/ $\mathrm{Fe}_{3} \mathrm{O}_{4}$}

Biochar is largely studied for its role in carbon sequestration and as a soil conditioner. It is produced from carbon-rich biomass by thermal decomposition in oxygen limited environments [76]. It can serve as an effective adsorbent for organic and inorganic materials $[25,77,78]$. The adsorption capacity of biochar is strongly influenced by its surface characteristics, which depend on the type of raw material and production conditions [79]. Sawdust is a by-product of sawing wood in sawmills and is often disposed of as waste or simply burned for bioenergy production. The manufacture of biochar from sawdust and the use of biochar as an adsorbent to remove water pollutants have the double function of using waste and reducing pollution [80]. The application of the magnetic Sawdust biochar $/ \mathrm{Fe}_{3} \mathrm{O}_{4}\left(\mathrm{SDB} / \mathrm{Fe}_{3} \mathrm{O}_{4}\right)$ for the elimination of $\mathrm{RB} 21$ dye from the aqueous solution has been reported by Nadeem et al. (2019). This adsorbent was used after preparation following the experimental protocol [14]. Batch adsorption experiments were affected by contact time (15-105 min), adsorbent dose (0.1-0.35 g), pH (3-11), temperature $\left(10-70^{\circ} \mathrm{C}\right)$ and dye concentration (30-180 mg. $\left.\mathrm{L}^{-1}\right)$. The elimination efficiency of RB21 increased with increasing contact time, but after 90 minutes there was no further improvement. The RB21 removal efficiency increased continuously with increasing adsorbent dose temperature. The neutral $\mathrm{pH}$ gives maximum adsorption of RB21. A decrease in 
removal efficiency was observed with the increase in the initial dye concentration. The maximum adsorption capacity calculated using Langmuir isotherm model was found to be $27.77778 \mathrm{mg} \cdot \mathrm{g}^{-1}$ [14].

Table 2 shows a comparison of the maximum adsorption capacities of various adsorbents for the RB21 dye. The maximum adsorption capacities for Chitosan/polyamidoamine and CZrP in this study were $666.67 \mathrm{mg} . \mathrm{g}^{-1}$ and $457 \mathrm{mg} . \mathrm{g}^{-1}$, respectively, representing higher values than most of the previous studies listed in Table 1. This indicates that the adsorbents were appropriate for the removal of RB21 phthalocyanine dye.

\section{Conclusions}

Many of the chemicals and dyes used in the textile industry have serious undesirable effects because their effects on the environment and on the public are not immediately apparent. Adsorption is one of the most effective advanced wastewater treatment processes used by industries to reduce dyes in the effluent. Locally available, efficient and inexpensive raw and processed materials could be used for the removal of dyes from its aqueous solution. Based on the literature reviewed here, the mechanism of adsorption of dyes on various adsorbents depends on the chemical nature of the materials and various physico-chemical parameters such as the $\mathrm{pH}$ of the solution, the initial concentration of the dye, the dosage of the adsorbent and the temperature of the system. Consequently, these factors must be taken into consideration when evaluating the adsorption capacity of different adsorbents.

\section{Conflict of Interest}

The authors declare no conflict of interest.

\section{References}

1. KANT R. Textile dyeing industry an environmental hazard. Nat. Sci. 04, 22, 2012.

2. DRUMOND CHEQUER F.M., DE OLIVEIRA G.A.R., ANASTACIO FERRAZ E.R., CARVALHO J., BOLDRIN ZANONI M.V., DE OLIVEIR D.P. Textile Dyes: Dyeing Process and Environmental Impact. in Eco-Friendly Textile Dyeing and Finishing InTech, 2013. doi:10.5772/53659.

3. KANT R. Textile dyeing industry an environmental hazard. Nat. Sci. 04, 22, 2012.

4. RODRÍGUEZ COUTO S. Dye removal by immobilised fungi. Biotechnology Advances 27, 227, 2009.

5. ARIVOLI S., THENKUZHALI M., MARTIN P., PRASATH D. Adsorption of rhodamine B by acid activated carbon-kinetic, thermodynamic and equilibrium studies. Orbital 1, 138, 2009.

6. FORGACS E., CSERHÁTI T., OROS G. Removal of synthetic dyes from wastewaters: A review. Environment International 30, 953, 2004.
7. OSUGI M.E., UMBUZEIRO G.A., ANDERSON M.A., ZANONI M.V.B. Degradation of metallophtalocyanine dye by combined processes of electrochemistry and photoelectrochemistry. in Electrochimica Acta 50, 5261, Pergamon, 2005.

8. PAGGA U., BROWN D. The degradation of dyestuffs: Part II Behaviour of dyestuffs in aerobic biodegradation tests. Chemosphere 15, 479, 1986.

9. BROWN D., LABOUREUR P. The degradation of dyestuffs: Part I Primary biodegradation under anaerobic conditions. Chemosphere 12, 397, 1983.

10. AHMED BASHA C., SARAVANATHAMIZHAN R., NANDAKUMAR V., CHITRA K., LEE C.W. Copper recovery and simultaneous COD removal from copper phthalocyanine dye effluent using bipolar disc reactor. Chem. Eng. Res. Des. 91, 552, 2013.

11. CAI M., SU J., ZHU Y., WEI X., JIN M., ZHANG H. DONG C., WEI Z. Decolorization of azo dyes Orange G using hydrodynamic cavitation coupled with heterogeneous Fenton process. Ultrason. Sonochem. 28, 302, 2016.

12. HU D., WANG P., MA Q., WANG L. Preparation of a cellulose-based adsorbent with covalently attached hydroxypropyldodecyldimethylammonium groups for the removal of C.I. Reactive Blue 21 dye from aqueous solution. Desalin. Water Treat. 57, 10604, 2016.

13. SOLANO A.M.S., MARTÍNEZ-HUITLE C.A., GARCIA-SEGURA S., EL-GHENYMY A., BRILLAS E. Application of electrochemical advanced oxidation processes with a boron-doped diamond anode to degrade acidic solutions of Reactive Blue 15 (Turqueoise Blue) dye. Electrochim. Acta 197, 210, 2016.

14. NADEEM F., JAMIL N., MOAZZAM A., AHMAD S.R., LATEEF, A., KHALID A., QADIR A., ALI A., MUNIR S. Synthesizing and Characterizing SawdustBiochar $/ \mathrm{Fe}_{3} \mathrm{O}_{4}$ Nanocomposites and its PotentialApplication in Textile Wastewater Treatment. Polish J. Environ. Stud. 28, 2311, 2019.

15. JOUAli A., SALHI A., AGUEDACH A., AARFANE A., GHAZZAF H., LHADI E.K., EL KRATI M., TAHIRI S. Photo-catalytic degradation of methylene blue and reactive blue 21 dyes in dynamic mode using $\mathrm{TiO}_{2}$ particles immobilized on cellulosic fibers. J. Photochem. Photobiol. A Chem. 383, 112013, 2019.

16. VATS A., MISHRA S. Identification and evaluation of bioremediation potential of laccase isoforms produced by Cyathus bulleri on wheat bran. J. Hazard. Mater. 344, 466, 2018.

17. ALI I., ASIM M., KHAN T.A. Low cost adsorbents for the removal of organic pollutants from wastewater. Journal of Environmental Management 113, 170, 2012.

18. SOČO E., KALEMBKIEWICZ J. Immobilizing and Removal of Cadmium and Rhodamine B from an Aqueous System by Converting Solid Waste from Poland; Studies of Equilibrium and Kinetic Sorption. Polish J. Environ. Stud. 29, 1,2020

19. NASEER R., AFZAL N., HASSAN Z. UL, SAEED S., MUJHAHID H., FARYAL S., ASLAM S., REHMAN H. UR. Effect of Bronsted Base on Topological Alterationof Rice Husk as an Efficient AdsorbentComparative to Rice Husk Ash for Azo Dyes. Polish J. Environ. Stud. doi:10.15244/pjoes/112353.

20. ADEGOKE K.A., BELLO O.S. Dye sequestration using agricultural wastes as adsorbents. Water Resources and Industry 12, 8, 2015.

21. DABROWSKI A. Adsorption - From theory to practice Advances in Colloid and Interface Science 93, 135, 2001. 
22. YAGUB M.T., SEN T.K., AFROZE S., ANG H.M. Dye and its removal from aqueous solution by adsorption: A review. Advances in Colloid and Interface Science 209, 172, 2014.

23. AHMAD A., MOHD-SETAPAR S.H., CHUONG C.S., KHATOON A., WANI W.A., KUMAR R., RAFATULLAH M. Recent advances in new generation dye removal technologies: Novel search for approaches to reprocess wastewater. RSC Advances 5, 30801, 2015.

24. MOJSOV K., ANDRONIKOV D., JANEVSKI A., KUZELOV A., GABER S. The application of enzymes for the removal of dyes from textile effluents. Adv. Technol. $\mathbf{5}, 81,2016$.

25. SULYMAN M., NAMIESNIK J., GIERAK A. Low-cost Adsorbents Derived from AgriculturalBy-products/Wastes for Enhancing ContaminantUptakes from Wastewater: A Review. Polish J. Environ. Stud. 26, 479, 2017.

26. MOHAMMED M.A., SHITU A., IBRAHIM A. Removal of Methylene Blue Using Low Cost Adsorbent: A Review. Research Journal of Chemical Sciences 4, 2014.

27. DONG M., ZHOU H., LIU W., HE C. Activated Carbon Prepared from Semi-Coke as anEffective Adsorbent for Dyes. Polish J. Environ. Stud. 29, 1137, 2020.

28. SALEEM J., SHAHID U. BIN, HIJAB M., MACKEY H., MCKAY G. Production and applications of activated carbons as adsorbents from olive stones. Biomass Conversion and Biorefinery 9, 775, 2019.

29. BOUZAIDA I., RAMMAH M.B. Adsorption of acid dyes on treated cotton in a continuous system. Mater. Sci. Eng. C 21, 151, 2002.

30. GANIYU S.A., AJUMOBI O.O., LATEEF S.A., SULAIMAN K.O., BAKARE I.A., QAMARUDDIN M., ALHOOSHANI K. Boron-doped activated carbon as efficient and selective adsorbent for ultra-deep desulfurization of 4,6-dimethyldibenzothiophene. Chem. Eng. J. 321, 651, 2017.

31. SHAKOOR H., IBRAHIM M., USMAN M., ADREES M., MEHMOOD M.A., ABBAS F., RASOOL N., RASHID U. Removal of Reactive Blue 21 from Aqueous Solution by Sorption and Solubilization in Micellar Media. J. Dispers. Sci. Technol. 37, 144, 2016.

32. ÇORUH S., ELEVLI S., DOĞAN G. Optimization study of adsorption of crystal violet and congo red onto sepiolite and clinoptilolite. Global NEST Journal 19, 2017.

33. EBRAHIMI R., MALEKI A., SHAHMORADI B., REZAEE R., DARAEI H., SAFARI M., ZANDSALIMI Y., BAHMANI P., PUTTAIAH S.H. Organic dye removal from aqueous media by using acid modified Clinoptilolite. J Adv. Env. Heal. Res 6, 118, 2018.

34. DOSA M., PIUMETTI M., BENSAID S., RUSSO N., BAGLIERI O., MIGLIETTA F., FINO D. Properties of the Clinoptilolite: Characterization and Adsorption Tests with Methylene Blue. J. Adv. Catal. Sci. Technol. 5, $1,2018$.

35. KOWALCZYK P., SPRYNSKYY M., TERZYK A.P., LEBEDYNETS M., NAMIEŚNIK J., BUSZEWSKI B. Porous structure of natural and modified clinoptilolites. J. Colloid Interface Sci. 297, 77, 2006.

36. WANG Y.-F., LIN F., PANG W.-Q. Ammonium exchange in aqueous solution using Chinese natural clinoptilolite and modified zeolite. J. Hazard. Mater. 142, 160, 2007.

37. KISMIR Y., KARAKUS S., SISMANOGLU T. Single and binary adsorption of reactive dyes from aqueous solutions onto clinoptilolite. J. Hazard. Mater. 184, 164, 2010.

38. KONG L., QIU F., ZHAO Z., ZHANG X., ZHANG T., PAN J., YANG D. Removal of brilliant green from aqueous solutions based on polyurethane foam adsorbent modified with coal. J. Clean. Prod. 137, 51, 2016.

39. BALDEZ E.E., ROBAINA N.F., CASSELLA R.J. Employment of polyurethane foam for the adsorption of Methylene Blue in aqueous medium. J. Hazard. Mater. 159, 580, 2008.

40. BOWEN H.J.M. Absorption by polyurethane foams; new method of separation. J. Chem. Soc. A Inorganic, Phys. Theor. Chem. 1082, 1970 doi:10.1039/J19700001082.

41. MANGALESHWARAN L., THIRULOGACHANDAR A., RAJASEKAR V., MUTHUKUMARAN C., RASAPPAN K. Batch and fixed bed column studies on nickel (II) adsorption from aqueous solution by treated polyurethane foam. J. Taiwan Inst. Chem. Eng. 55, 112, 2015.

42. DE JESUS DA SILVEIRA NETA J., COSTA MOREIRA G., DA SILVA C.J., REIS C., REIS E.L. Use of polyurethane foams for the removal of the Direct Red 80 and Reactive Blue 21 dyes in aqueous medium. Desalination 281, 55, 2011

43. MUZZARELLI R.A.A., RICCARDO A.A., MUZZARELLI RICCARDO A.A. MUZZARELLI. Natural chelating polymers; alginic acid, chitin, and chitosan. Natural Chelating Polymers; Alginic acid, Chitin, and Chitosan 1973.

44. LI B., SHAN C.L., ZHOU Q., FANG Y., WANG Y.L., XU F., HAN L.R., IBRAHIM M., GUO L.B., XIE G.L., SUN G.C. Synthesis, characterization, and antibacterial activity of cross-linked chitosan-glutaraldehyde. Mar. Drugs 11, 1534, 2013.

45. VÁZQUEZ J.A., RODRÍGUEZ-AMADO I., MONTEMAYOR M.I., FRAGUAS J., DEL GONZÁLEZ M.P., MURADO M.A. Chondroitin sulfate, hyaluronic acid and chitin/chitosan production using marine waste sources: Characteristics, applications and eco-friendly processes: A review. Marine Drugs 11, 747, 2013.

46. VENKATESAN J., BHATNAGAR I., KIM S.K. Chitosanalginate biocomposite containing fucoidan for bone tissue engineering. Mar. Drugs 12, 300, 2014.

47. WEN Z.S., LIU L.J., QU Y. LE, OUYANG X.K., YANG L.Y., XU Z.R. Chitosan nanoparticles attenuate hydrogen peroxide-induced stress injuryin mouse macrophage RAW264.7 cells. Mar. Drugs 11, 3582, 2013.

48. YI N., WU Y., FAN L., HU S. Remediating CdContaminated Soils UsingNatural and ChitosanIntroduced Zeolite, Bentonite, and Activated Carbon. Polish J. Environ. Stud. 28, 1461, 2019.

49. ALAKHRAS F., AL-SHAHRANI H., AL-ABBAD E., AL-RIMAWI F., OUERFELLI N. Removal of Pb(II) Metal Ions from AqueousSolutions Using Chitosan-Vanillin Derivativesof Chelating Polymers. Polish J. Environ. Stud. 28, 1523, 2019.

50. KYZAS G., BIKIARIS D. Recent Modifications of Chitosan for Adsorption Applications: A Critical and Systematic Review. Mar. Drugs 13, 312, 2015.

51. ZERAATKAR MOGHADDAM A., GHIAMATI E., POURASHURI A., ALLAHRESANI A. Modified nickel ferrite nanocomposite/functionalized chitosan as a novel adsorbent for the removal of acidic dyes. Int. J. Biol. Macromol. 120, 1714, 2018.

52. VAKILI M., RAFATULLAH M., IBRAHIM M.H., ABDULLAH A.Z., GHOLAMI Z., SALAMATINIA B. Enhancing reactive blue 4 adsorption through chemical modification of chitosan with hexadecylamine and 3-aminopropyl triethoxysilane. J. Water Process Eng. 15, 49, 2017. 
53. DOSHI B., REPO E., HEISKANEN J.P., SIRVIÖ J.A., SILLANPÄ̈̈ M. Sodium salt of oleoyl carboxymethyl chitosan: A sustainable adsorbent in the oil spill treatment. J. Clean. Prod. 170, 339, 2018.

54. WANG P., MA Q., HU D., WANG L. Removal of Reactive Blue 21 onto magnetic chitosan microparticles functionalized with polyamidoamine dendrimers. React. Funct. Polym. 91-92, 43, 2015.

55. ZARGHAMI Z., AKBARI A., LATIFI A.M., AMANI M.A. Design of a new integrated chitosan-PAMAM dendrimer biosorbent for heavy metals removing and study of its adsorption kinetics and thermodynamics. Bioresour. Technol. 205, 230, 2016.

56. WU Z., ZHANG L., GUAN Q., NING P., YE D. Preparation of $\alpha$-zirconium phosphate-pillared reduced graphene oxide with increased adsorption towards methylene blue. Chem. Eng. J. 258, 77, 2014.

57. BHATT R., AGEETHA V., RATHOD S.B., PADMAJA P. Self-assembled chitosan-zirconium phosphate nanostructures for adsorption of chromium and degradation of dyes. Carbohydr. Polym. 208, 441, 2019.

58. ABUTARTOUR A., JIA Y., MAJDOUB L. EL XU Q. A new hierarchical porous zirconium phosphate membrane and its adsorption properties. Microporous Mesoporous Mater. 196, 1, 2014.

59. ZHAO D., YU Y., CHEN J.P. Treatment of lead contaminated water by a PVDF membrane that is modified by zirconium, phosphate and PVA. Water Res. 101, 564, 2016.

60. ADEL A.M., ABD EL-WAHAB Z.H., IBRAHIM A.A., AL-SHEMY M.T. Characterization of microcrystalline cellulose prepared from lignocellulosic materials. Part II: Physicochemical properties. Carbohydr. Polym. 83, 676, 2011.

61. ELANTHIKKAL S., GOPALAKRISHNAPANICKER U., VARGHESE S., GUTHRIE J.T. Cellulose microfibres produced from banana plant wastes: Isolation and characterization. Carbohydr. Polym. 80, 852, 2010.

62. ASHORI A., NOURBAKHSH A. Performance properties of microcrystalline cellulose as a reinforcing agent in wood plastic composites. Compos. Part B Eng. 41, 578, 2010.

63. KALE R.D., POTDAR T., GORADE V. Treatment of C.I. reactive blue- 21 effluent by microcrystalline cellulose grafted with APTES: Kinetics, isotherm and thermodynamic study. Sustain. Environ. Res. 1, 7, 2019.

64. LIU L., CHEN H., SHIKO E., FAN X., ZHOU Y., ZHANG G., LUO, X., HU, X. (Eric). Low-cost DETA impregnation of acid-activated sepiolite for $\mathrm{CO}_{2}$ capture. Chem. Eng. J. 353, 940, 2018

65. ZHANG J., ZHANG Y., LUDWIG W., ROWENHORST,D., VOORHEES P.W., POULSEN H.F. Three-dimensional grain growth in pure iron. Part I. statistics on the grain level. Acta Mater. 156, 76, 2018.

66. DUMAN O., TUNÇ S., GÜRKAN POLAT T. Adsorptive removal of triarylmethane dye (Basic Red 9) from aqueous solution by sepiolite as effective and low-cost adsorbent. Microporous Mesoporous Mater. 210, 176, 2015.
67. LI Y., WANG M., SUN D., LI Y., WU T. Effective removal of emulsified oil from oily wastewater using surfactantmodified sepiolite. Appl. Clay Sci. 157, 227, 2018.

68. GABER S., ABU HAIJA M., PRIYABRATA P., SELVARAJ M., BANAT F. Removal of iron from industrial lean methyldiethanolamine solvent by adsorption on sepiolite. Sep. Sci. Technol. 53, 404, 2018.

69. SANTOS S.C.R., BOAVENTURA R.A.R. Adsorption of cationic and anionic azo dyes on sepiolite clay: Equilibrium and kinetic studies in batch mode. J. Environ. Chem. Eng. 4, 1473, 2016.

70. ERDOĞAN ALVER B. Hydrogen adsorption on natural and sulphuric acid treated sepiolite and bentonite. Int. J. Hydrogen Energy 43, 831, 2018.

71. YIN H., KONG M., FAN C. Batch investigations on P immobilization from wastewaters and sediment using natural calcium rich sepiolite as a reactive material. Water Res. 47, 4247, 2013.

72. DOĞAN M., ÖZDEMIR Y., ALKAN M. Adsorption kinetics and mechanism of cationic methyl violet and methylene blue dyes onto sepiolite. Dye. Pigment. 75, 701, 2007.

73. DEMIRBAS E., NAS M.Z. Batch kinetic and equilibrium studies of adsorption of Reactive Blue 21 by fly ash and sepiolite. Desalination 243, 8, 2009.

74. SUN D., ZHANG X., WU Y., LIU X. Adsorption of anionic dyes from aqueous solution on fly ash. J. Hazard. Mater. 181, 335, 2010.

75. WANG P., YAN T., MA Q., HU D., WANG L. Preparation of hydrazine-modified $\mathrm{CMC} / \mathrm{Fe} 3 \mathrm{O} 4$ hybrid magnetic particles for adsorption of Reactive Blue 21 from water. Desalin. Water Treat. 57, 14986, 2016.

76. SOHI S.P., KRULL E., LOPEZ-CAPEL E., BOL R. A review of biochar and its use and function in soil. in Advances in Agronomy 105, 47, Academic Press Inc., 2010.

77. MA F., QU R., SUN C., WANG C., JI C., ZHANG Y., YIN P. Adsorption behaviors of $\mathrm{Hg}(\mathrm{II})$ on chitosan functionalized by amino-terminated hyperbranched polyamidoamine polymers. J. Hazard. Mater. 172, 792, 2009.

78. LU Y., CHEN J., ZHAO L., ZHOU Z., QIU C., LI Q. Adsorption of Rhodamine B from Aqueous Solution by Goat Manure Biochar: Kinetics, Isotherms, and Thermodynamic Studies. Polish J. Environ. Stud. 29, 1, 2020.

79. AHMAD M., RAJAPAKSHA A.U., LIM J.E., ZHANG M., BOLAN N., MOHAN D., VITHANAGE M., LEE S.S., OK Y.S. Biochar as a sorbent for contaminant management in soil and water: A review. Chemosphere 99, 19, 2014.

80. LOU K., RAJAPAKSHA A.U., OK Y.S., CHANG S.X. Pyrolysis temperature and steam activation effects on sorption of phosphate on pine sawdust biochars in aqueous solutions. Chem. Speciat. Bioavailab. 28, 42, 2016.

81. HANDA B.K. Treatment and recycle of wastewater in industry. Natl. Environ. Eng. Res. Inst. 21, 65, 75, 76, 78, 82, 85, 94, 1991. 